\title{
Ant Community Structure (Hymenoptera: Formicidae) in Two Neighborhoods with Different Urban Profiles in the City of São Paulo, Brazil
}

\author{
Alcione Piva and Ana Eugênia de Carvalho Campos \\ Unidade Laboratorial de Referência em Pragas Urbanas, Instituto Biológico, Avenida Conselheiro Rodrigues Alves, \\ 1252 São Paulo, SP, Brazil \\ Correspondence should be addressed to Ana Eugênia de Carvalho Campos, anaefari@biologico.sp.gov.br \\ Received 24 May 2011; Revised 18 July 2011; Accepted 1 August 2011 \\ Academic Editor: Fernando Fernández
}

Copyright () 2012 A. Piva and A. E. C. Campos. This is an open access article distributed under the Creative Commons Attribution License, which permits unrestricted use, distribution, and reproduction in any medium, provided the original work is properly cited.

Some ant species are highly abundant in cities, may form huge unicolonial populations with thousands of individuals able to displace native fauna, and impoverish ecological relationships in urban environments. In this work, we study the ant community in two neighborhoods with different urban profiles, one recently populated and another from the 1900s in the city of São Paulo, Brazil. Two hundred and ninety houses were sampled with baits for ant collections. Results show that the recent urbanized neighborhood with greater disturbance favors opportunistic and dominant species to colonize it, like Tapinoma melanocephalum. We also made a temporal analysis in the ancient neighborhood, collecting ants after ten years from a first survey. T. melanocephalum has a broader range than ten years ago, displaced other ant species, but confronts with Pheidole megacephala that was not found in the recent urbanized neighborhood.

\section{Introduction}

Some ant species promote severe problems in Brazil, especially exotic ones with invading status, which were accidentally introduced in the country and may be found with huge populations, displacing native ant fauna, other arthropod species, and even vertebrates [1]. Among the most common invading species found in Brazilian cities, Pheidole megacephala (Fabricius, 1783), Tapinoma melanocephalum (Fabricius, 1793), Nylanderia fulva (Mayr, 1862), and Paratrechina longicornis (Latreille, 1802) [2-5] are highlighted.

Around the world, recordings on P. megacephala point this species as one of the most dominant and aggressive tramp ant species. In 1908, the big-headed ant invaded a Caribbean island, and surveys show that this is the only ant species found in that environment [6]. The same data were found in two, from five islands surveyed in Florida [7]. In Australia, P. megacephala displaced dominant
Dolichoderinae species, Camponotini, and other Pheidole species in forested areas [8]. The big-headed ant biomass in areas where it dominates is 18 times greater than the native ant species biomass where it does not occur [9]. In a study conducted in urban areas from the Brazilian Cerrado, P. megacephala predominated in areas with low conservation efforts [5].

Tapinoma melanocephalum originated from the IndoPacific region is one of the ant species with broader distribution [10]. As in other parts of the world, it was the most abundant species in a neighborhood in the city of São Paulo [3], in a hospital in the Central-Eastern Brazil [11], in residences in Ilhéus [2], Uberlândia [4], and Mogi das Cruzes [12].

But not only are these common worldwide tramp ants found in Brazilian cities. Others, native or exotic, are also household invaders. Brachymyrmex sp., Solenopsis saevissima (F. Smith, 1855), S. invicta Buren, 1972, Monomorium spp., 
Crematogaster sp., Cyphomyrmex sp., Cardiocondyla sp., Linepithema humile (Mayr, 1868), Dorymyrmex sp., Camponotus spp., and Pachycondyla sp. [2, 3, 13, 14].

Studies have focused on the biology of invading species and found out that they share some common characteristics like multiple queens, polidomic nests with a huge cooperation net among the nests, without any aggressive behavior [15], and also their clear association with disturbed environments [16]. On the other hand, one might understand which are the patterns and characteristics in the urban environment to shelter invading ant species and use this knowledge to promote satisfactory management and control. In this way, Clarke et al. [17] examined soil characteristics and type of vegetation in urban parks in San Francisco, USA, and concluded that soil moisture positively affects ant species richness, and percent of natural area that is forested was negatively related. Forys and Allen [18] established a positive correlation between exotic and native ant species in Florida. The authors stated that the same biotic and abiotic characteristics may favor both species. But they highlighted that an increase on urban sprawl leads to an increase on the number of exotic ant species, once they are known to displace native ant fauna.

In New York, a study revealed that besides introduced species that are usually favored by disturbance, this process must be much more complex than it is known [19]. In this survey, Tetramorium caespitum (L.), a generalist exotic species that nests in cracks on sidewalks, was the most collected ant, but in most streets, it occurred with other ant species, exotic or native to the USA. This same ant species was also collected in a survey conducted in the surroundings of Montreal close to a forested area [20].

For this purpose, two neighborhoods were surveyed, and ant presence was associated to recent or ancient urbanization and other abiotic factors furnished by man.

\section{Material and Methods}

2.1. Surveyed Neighborhoods. Ant collections were made in households in two neighborhoods in the city of São Paulo: Vila Mariana and Itaquera.

Itaquera is located in the Eastern side of the city of São Paulo $20 \mathrm{Km}$ apart from downtown. Its $55.32 \mathrm{~km}^{2}$ have low- and medium-density residential areas, few apartment buildings, an environmental protection area with a rainforest remaining with 867.60 hectares, and an industrial and an agriculture area. Besides the first residences date from the 1900 s, the urbanization process initiated 35 years ago and is still growing.

Vila Mariana is $26.87 \mathrm{~km}^{2}, 5 \mathrm{Km}$ from downtown, with median- and high-density residential blocks, with many apartment buildings and commercial areas. There are no industrial, agricultural, or environmental protection areas. Urbanization process started in the 1900s, and most houses are from the 1950s. Today, some houses are being substituted by modern apartment buildings, but still ancient houses are found, and most of them are well preserved.

Ant collections were performed in Vila Mariana in two periods: from December 1998 to October 1999 and ten years later, from December 2009 to January 2011. In Itaquera, collections were made from December 2009 to January 2011.

Two hundred and ninety houses were sampled: 132 in Vila Mariana in the period 1998/1999, 79 in Vila Mariana (2009-2011), and 79 in Itaquera (2009-2011).

Households were randomly chosen. We could repeat the ant collection in the same 25 houses in Vila Mariana in 20092011 after 10 years. The other 54 houses were surveyed for the first time in the recent years. Baits based on dehydrated liver, pineapple cake, and honey were set in $7 \mathrm{~cm}$ length straws which were placed in the houses, 15 baits in each house and three in each room: living room, bedroom, kitchen, bathroom, and outdoors (peridomiciliar area). In addition, manual collections were also performed using brushes and a bottle-type vacuum. The baits were left for 24 hours, and collected ants were taken to the laboratory for identification and counting. In addition to the collections, it was also filled in a form with data relating to the environment as house conservation, cleanness, number of children, and presence of pets.

2.2. Statistical Analysis. We used descriptive statistics with graphics and tables. Categorical and numerical variables for neighborhood characterization were obtained from a form filled in for each ant collection (Table 1). We computed percentage values for categorical analysis (number of floors and children, pet and garden presence) and the mean number for numerical variables (number of rooms per house, number of residents and house age).

Association analysis was calculated for the five most collected ant species in the three samples. For that purpose, the Pearson's chi-square test was used or the Fisher's exact test (for expected values less than 5).

For numerical variables, the Mann-Whitney test was used to compare two categories, and the Kruskal-Wallis Test was used to compare three or more categories due to the absence of normal distribution from the variables [21]. The level of $5 \%$ of significance was used $(P<0.05)$. The SAS system for Windows (statistical analysis system), version 8.02 , was used for statistical analysis [22].

Relative frequency was calculated to analyze the most frequent ant species indoors and outdoors in each neighborhood, in each period of collection.

Shannon diversity index, equitability index, and Simpson's Index were calculated with the BioDap software [23] in order to record ant community in the neighborhoods.

\section{Results}

3.1. Ant Community. It was collected 7.249 ant specimens in the 132 collections in Vila Mariana in 1998/1999, 6.477 specimens in the 79 collections in Vila Mariana in 20092011, and 12.054 specimens in the 79 collections in Itaquera in 2009-2011 (Table 2).

In Itaquera, 33 ant species were found, most native to Brazil, but 4 were exotic ones. In Vila Mariana, we collected 23 ant species in 1998/1999, 3 were exotic, and from 20092011 we collected 25 ant species and 4 were exotic. 
TABLE 1: Data from surveyed households in Vila Mariana and Itaquera neighborhoods in the city of São Paulo, Brazil.

\begin{tabular}{|c|c|c|c|c|}
\hline Control number & () Itaquera & & () Vila Mariana & Date: // \\
\hline \multicolumn{5}{|l|}{ Address } \\
\hline Contact & & & () Single-story house & () Two-story house \\
\hline Number of rooms () & Number of residents () & & Children: () Yes & () No \\
\hline \multirow[t]{2}{*}{ House age: } & & & Garden: () Yes & () No \\
\hline & & & Pets: () Yes & () No \\
\hline Conservation condition & () Very good & () Good & () $\mathrm{Bad}$ & () Very bad \\
\hline Cleanness condition & () Very good & () Good & () $\mathrm{Bad}$ & () Very bad \\
\hline
\end{tabular}

Tapinoma melanocephalum was the most abundant species in the three collections (VM 1998/1999, VM 20092011, and ITA 2009-2011).

In Vila Mariana, ten years later, it was found an increase on T. melanocephalum frequency and a decrease on the other ant species frequency as N. fulva, Brachymyrmex sp. 1, and Solenopsis sp., which are all native to Brazil. L. humile, also native to Brazil and found in 1998/1999, was not found in the surveys from 2009 to 2011 . This is a species that could have had success in dominating the neighborhood. But the exotic big-headed ant, $P$. megacephala, expanded its foraging range ten years later. Besides its high frequency in Vila Mariana, $P$. megacephala was not found in Itaquera.

Ten years ago, N. fulva was the most frequent species, present in more than $40 \%$ of the sampled houses in Vila Mariana. Its occurrences were even indoors and outdoors. In 1998/1999, P. longicornis was also found outdoors with N. fulva. Our last survey from 2009 to 2011 showed that P. longicornis' frequency increased almost 3 times (Table 2), but its occurrence was limited to the peridomiciliar area. As $N$. fulva, P. longicornis is also an invasive ant species and can be displacing the native $N$. fulva. But the association analysis of $N$. fulva was negative with T. melanocephalum and P. megacephala (Figure 1) in the survey from 1998 to 1999. Thus, N. fulva may not succeed in colonizing Vila Mariana all these years, once it competed with three other invasive ants. As we calculated the association only among the five most frequent species, P. longicornis did not enter in 1998/1999 analysis.

From 2009 to 2011, few associations could be established among the ant species, but $P$. longicornis frequency increased and showed negative association with $P$. megacephala (Figure 2).

T. melanocephalum was mainly collected indoors (living rooms, bedrooms, kitchens, and bathrooms). When we compared samples from T. melanocephalum in 1998/1999 and ten years later, its relative frequency increased from $18 \%$ to $53 \%$ inside houses. $P$. megacephala indoor frequency was the same ten years later, but it expanded its foraging areas outdoors from 2009 to 2011. Brachymyrmex sp. 1 and Solenopsis sp. frequencies decreased in the outdoors in the last samples (Figure 3).

We analyzed the same 25 houses surveyed in 1998/1999 and 2009-2011, and data do not show significant differences from the 79 surveyed houses analyzed together (Figure 4).

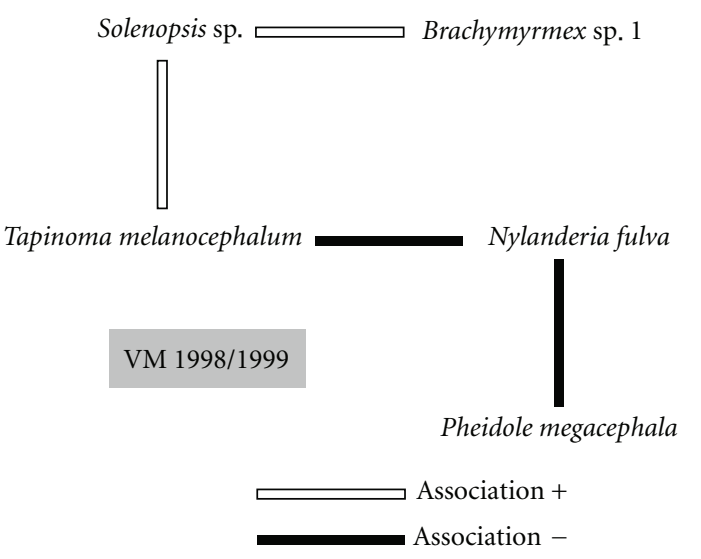

Figure 1: Community structure of house-infesting ants in Vila Mariana, São Paulo, from 1998 to 1999.

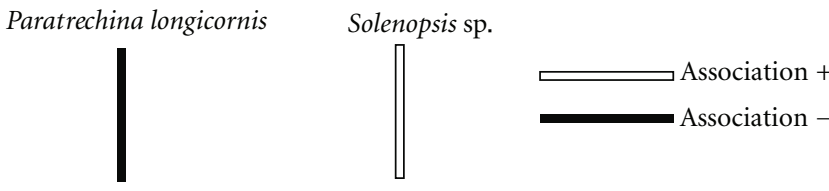

Pheidole megacephala Tapinoma melanocephalum

$$
\text { VM 2009/2011 }
$$

Figure 2: Community structure of house-infesting ants in Vila Mariana, São Paulo, from 2009 to 2011.

T. melanocephalum and P. megacephala are the most frequent species, and $N$. fulva decreased its frequency in ten years (Figure 4).

The number of ant species per house varied from 1 to 10 (Figure 5). The number of houses with only one ant species increased in the survey from 2009 to 2011 in Vila Mariana, due to T. melanocephalum increase.

In the opposite, Itaquera shows more houses with more ant species, compared to Vila Mariana.

The diversity indexes revealed that Vila Mariana has a more diverse and balanced ant community compared to Itaquera. The temporal analysis showed a decrease in the ant diversity in Vila Mariana (Table 3). 
TABle 2: Ant species richness and relative frequency in Vila Mariana (VM 1998/1999 and VM 2009-2011) and Itaquera (ITA 2009-2011), in the city of São Paulo, Brazil.

\begin{tabular}{|c|c|c|c|}
\hline Taxon & $\begin{array}{c}\text { Relative frequency (\%) } \\
\text { VM 1998/1999 }\end{array}$ & $\begin{array}{c}\text { Relative frequency (\%) } \\
\text { VM 2009-2011 }\end{array}$ & $\begin{array}{c}\text { Relative frequency (\%) } \\
\text { ITA 2009-2011 }\end{array}$ \\
\hline Acromyrmex sp. 1 & - & - & 3.80 \\
\hline Brachymyrmex sp. 1 & 36.36 & 17.72 & 8.86 \\
\hline Brachymyrmex sp. 2 & - & 6.33 & - \\
\hline Brachymyrmex sp. 3 & - & 1.27 & - \\
\hline Camponotus (Tanaemyrmex) sp. 1 & 6.82 & 1.27 & 1.27 \\
\hline Camponotus crassus (Mayr, 1862) & - & 1.27 & 7.59 \\
\hline Camponotus rufipes (Fabricius, 1775) & - & - & 6.33 \\
\hline Camponotus sp. 1 & 1.52 & - & - \\
\hline Camponotus sp. 2 & - & 2.53 & - \\
\hline Cardiocondyla sp. 1 & 15.15 & - & 1.27 \\
\hline Crematogaster sp. & 1.52 & - & 1.27 \\
\hline Cyphomyrmex sp. 1 & 0.76 & 1.27 & 3.80 \\
\hline Dorymyrmex sp. 1 & 0.76 & - & 3.80 \\
\hline Ectatomma sp. 1 & - & 1.27 & 5.06 \\
\hline Nesomyrmex sp. 1 & 5.30 & 2.53 & 16.46 \\
\hline Linepithema humile (Mayr, 1868) & 10.61 & - & - \\
\hline Linepithema sp. 1 & - & - & 3.80 \\
\hline Linepithema sp. 2 & - & - & 1,27 \\
\hline Monomorium floricola Jerdon, 1851 & - & 6.33 & 5.06 \\
\hline Monomorium pharaonis (Linnaeus, 1758) & - & - & 2,53 \\
\hline Monomorium sp. & 6.06 & - & - \\
\hline Nylanderia fulva (Mayr, 1862) & 40.15 & 5.06 & 17.72 \\
\hline Octostruma sp. 1 & - & - & 1.27 \\
\hline Pachycondyla sp. 1 & 0.76 & 2.53 & 3.80 \\
\hline Pachycondyla sp. 2 & - & - & 1.27 \\
\hline Paratrechina longicornis (Latreille, 1802) & 6.06 & 17.72 & 22.78 \\
\hline Pheidole dimidiata Emery, 1894 & 7.58 & 2.53 & 1.27 \\
\hline Pheidole fallax Mayr, 1870 & 3.79 & - & 1,27 \\
\hline Pheidole megacephala (Fabricius, 1783) & 24.24 & 37.97 & - \\
\hline Pheidole risii Forel, 1892 & 0.76 & 1.27 & 1.27 \\
\hline Pheidole sp. 1 & - & 7,59 & 2,53 \\
\hline Pheidole sp. 2 & - & - & 1.27 \\
\hline Pheidole sp. 3 & - & - & 3.80 \\
\hline Pheidole sp. 4 & - & 7.59 & 2.53 \\
\hline Pheidole sp. 5 & - & - & 1.27 \\
\hline Pheidole sp. 6 & 0.76 & 1.27 & - \\
\hline Pheidole sp. 7 & 0.76 & - & - \\
\hline Pheidole nubila Emery, 1906 & 0.76 & - & 6.33 \\
\hline Hypoponera sp. 1 & - & 1.27 & - \\
\hline Pseudomyrmex termitarius (Smith, 1855) & - & 1.27 & 1.27 \\
\hline Solenopsis sp. & 23.48 & 7.59 & 25.32 \\
\hline Solenopsis (Diplorhoptrum) sp. 1 & 12.12 & 3.80 & 2.53 \\
\hline Tapinoma melanocephalum (Fabricius, 1793) & 19.70 & 56.96 & 79.75 \\
\hline Wasmannia auropunctata (Roger, 1863) & - & 3.80 & - \\
\hline
\end{tabular}




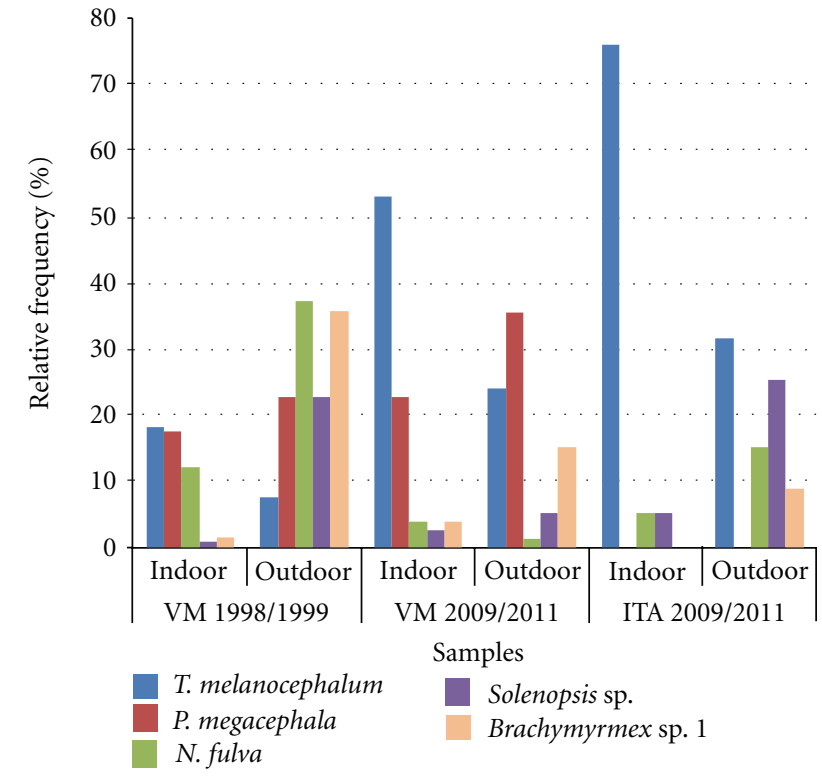

Figure 3: Relative frequencies of the most common sampled ant species in Vila Mariana from 1998 to 1999 (VM 1998/1999), 2009 to 2011 (VM 2009-2011) and Itaquera, from 2009 to 2011 (ITA 2009/2011), in the city of São Paulo.

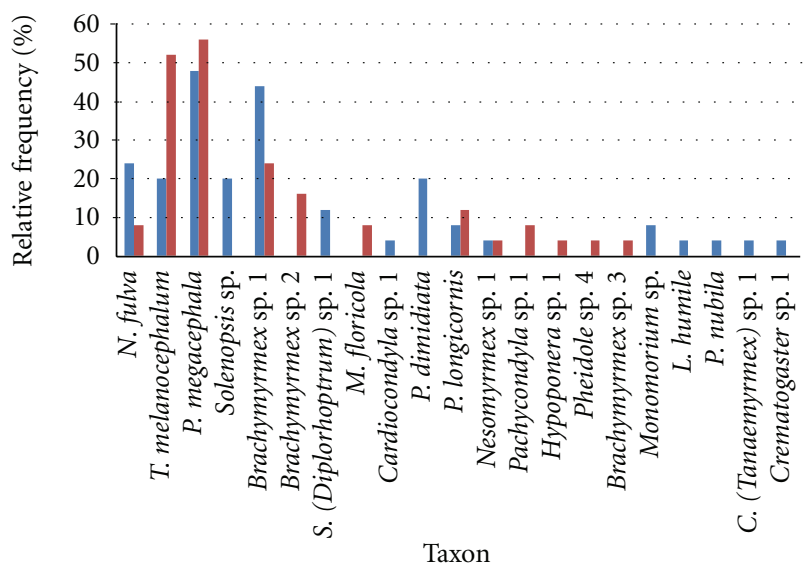

VM 1998/1999

VM 2009/2011

FIGURE 4: Relative frequency of ant species collected in the same 25 houses in 1998/1999 and 2009-2011, in Vila Mariana (VM), São Paulo, Brazil.

3.2. Neighborhood Profiles. Itaquera is a neighborhood with small- and single-story houses, recently constructed, with more children and few areas of gardens and backyards. The worst conserved and with less cleanness houses were found there. In Vila Mariana, houses are bigger, more ancient than in Itaquera, with a large number of two-story houses, and with more gardens and backyards (Table 4).

3.3. Comparative Analysis between Ant Samples and Environment Characteristics. The Mann-Whitney and KruskalWallis tests showed that more ant species were found in

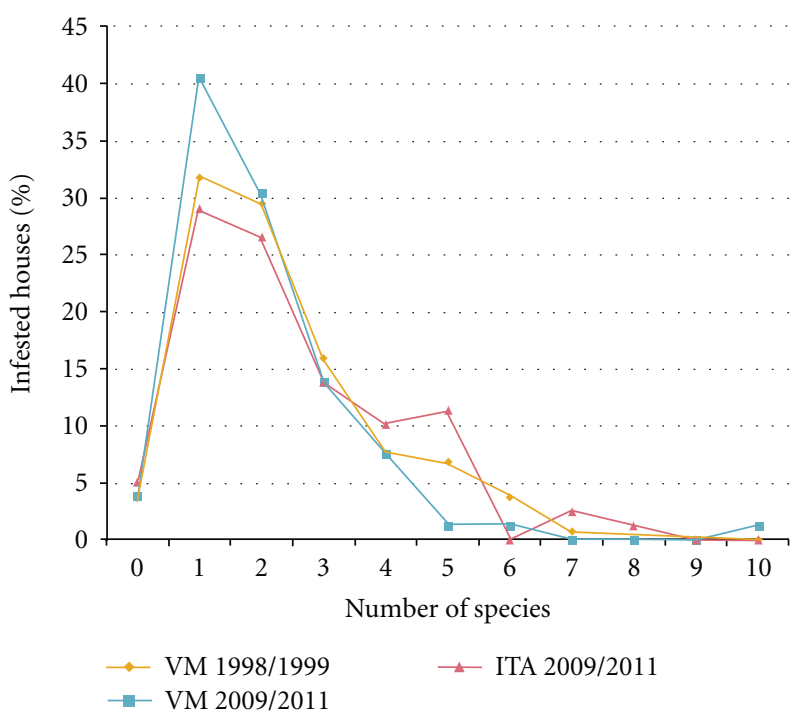

FIGURE 5: Number of ant species collected per house in Vila Mariana (VM), 1998/1999 and 2009-2011, and Itaquera (ITA) in the city of São Paulo, Brazil.

TABLE 3: Species richness, Shannon-Wiener diversity index $\left(\mathrm{H}^{\prime}\right)$, equitability (E), and Simpson's diversity index (D) in Vila Mariana and Itaquera, in the city of São Paulo.

\begin{tabular}{lccc}
\hline & $\begin{array}{c}\text { Vila Mariana } \\
(1998 / 1999)\end{array}$ & $\begin{array}{c}\text { Vila Mariana } \\
(2009-2011)\end{array}$ & $\begin{array}{c}\text { Itaquera } \\
(2009-2011)\end{array}$ \\
\hline Species richness & 24 & 25 & 33 \\
$\mathrm{H}^{\prime}$ & 1.87 & 1.42 & 0.96 \\
$\mathrm{E}$ & 0.60 & 0.44 & 0.27 \\
$\mathrm{D}$ & 0.207 & 0.381 & 0.648 \\
\hline
\end{tabular}

TABLE 4: Characteristics of houses sampled in Vila Mariana and Itaquera, in the city of São Paulo, Brazil.

\begin{tabular}{lccc}
\hline Characteristic & $\begin{array}{c}\text { Vila Mariana } \\
(1998 / 1999)\end{array}$ & $\begin{array}{c}\text { Vila Mariana } \\
(2009-2011)\end{array}$ & $\begin{array}{c}\text { Itaquera } \\
(2009-2011)\end{array}$ \\
\hline $\begin{array}{l}\text { One-story houses (\%) } \\
\text { Two-story houses (\%) }\end{array}$ & 11.4 & 15.2 & 74.7 \\
$\begin{array}{l}\text { Mean number of } \\
\text { rooms per house }\end{array}$ & 9.4 & 84.8 & 25.3 \\
$\begin{array}{l}\text { Mean of residents per } \\
\text { house }\end{array}$ & 3.4 & 3.4 & 4.8 \\
$\begin{array}{l}\text { Houses with children } \\
\text { (\%) }\end{array}$ & 20.8 & 16.4 & 43.5 \\
$\begin{array}{l}\text { Mean house age } \\
\text { (years) }\end{array}$ & 44.8 & 49.9 & 25.1 \\
$\begin{array}{l}\text { Houses with gardens } \\
\text { (\%) }\end{array}$ & 85.6 & 72.1 & 34.1 \\
Houses with pets (\%) & 47.3 & 50.6 & 60.7 \\
\hline
\end{tabular}

single-story houses $(P=0.007)$, mainly in their outdoors, and in both neighborhoods, in both periods of collections. $T$. melanocephalum was more frequent in houses with children $(P=0.001)$. On the other hand, $P$. megacephala was more 
frequent in houses without children $(P=0.007)$. Yet, according to the Mann-Whitney test, the highest frequencies of ant specimens outdoors $(P<0.001)$, as the number of ant species $(P=0.002)$, are higher in external areas in houses with gardens and backyards. $P$. megacephala is mainly found in houses with gardens and backyards $(P<0.001)$. Houses without pets showed the highest species richness even indoors $(P=0.042)$, and outdoors $(P=0.016)$, the worst conserved houses showed species richness $(P=0.042)$ and pour cleanness houses showed higher ant abundance $(P=0.047)$.

\section{Discussion}

Tapinoma melanocephalum was the most common species in Vila Mariana in both studied periods and in Itaquera. Other surveys in urban areas also pointed to this same species $[4,14,24]$ as one of the most common ants in urban environments. T. melanocephalum is distributed throughout the world [10] and recruits a huge number of workers when a food resource is found [13], explaining its high abundance in our samples. As in São Paulo, in a survey conducted in New York in 2010, an exotic species was the most collected [19].

After ten years, it expanded its range in Vila Mariana as did P. megacephala and P. longicornis, contributing to the displacement of N. fulva, Brachymyrmex sp. 1, and Solenopsis sp. populations. $P$. megacephala is an aggressive and dominant ant species known to displace native ant fauna where it is introduced [7-9]. P. longicornis was pointed by Forys and Allen [18] as the most common ant species in the region of Lower Florida Keys, and it was positively associated with the increase of urban development.

In a survey conducted in 1994 in a banana crop in southeastern Brazil, Fowler et al. [25] reported negative association between T. melanocephalum and P. longicornis. From 80 surveyed banana farms, 31 showed P. longicornis and 18 had $T$. melanocephalum presence, and in none of them both species were collected together. In our study, $P$. longicornis association was not analyzed with other ant species in Vila Mariana in 1998/1999 once its frequency and abundance were too low. But frequency data compared in both collected periods in Vila Mariana showed that this species is expanding its range. When association analysis was calculated to the most recent ant collections in Vila Mariana, $P$. longicornis only showed negative association with P. megacephala. This is explained by the fact that $P$. longicornis was not collected inside households, only outdoors where we also found $P$. megacephala. As T. melanocephalum occurrence is more frequent indoors than outdoors, they did not establish any ecological association.

In the central-eastern Brazil, surveys showed P. megacephala in ancient neighborhoods, with intense commercial activities and without expressive green areas [4], environments similar to Vila Mariana. Pacheco and Vasconcelos [5] also found this species in commercial areas and poorly preserved. In fact, commercial areas were also reported in a survey conducted by Menke et al. [26] with several invading ant species, as we have found in Vila Mariana. Therefore, it cannot be affirmed that this species prefers such urban environments. The establishment and dominance of invading species are related to several biotic and abiotic factors that must be better studied.

For T. melanocephalum to establish its nests, cleanness and resident habitats seem not to be relevant, but they can be decisive to their high frequency and abundance. In Itaquera, around $43 \%$ of the total sampled houses showed regular or very bad cleanness, and almost $25 \%$ were poorly preserved. Such conditions favor food offering and shelter [27] in order to promote suitable conditions for ant colonies development. Therefore, the best condition observed in Itaquera to be a good environment for $T$. melanocephalum was the absence of other ant species, as dominant as the ghost ant is, like $P$. megacephala.

Children presence may favor T. melanocephalum establishment, once data were similar in Vila Mariana after one decade and when the neighborhoods were separately analyzed. Children may offer more food on several rooms of the house favoring this opportunistic ant species.

A decrease on the ant diversity in Vila Mariana after 10 years was found when we calculated the Shannon-Wiever diversity index, but even though it is higher than in Itaquera. The low ant diversity in Itaquera must be attributed to $T$. melanocephalum abundance. Simpson's index corroborates this statement, once its value was higher in Itaquera, pointing to the dominance of one ant species.

An interesting data showed by the comparative analysis using the Mann-Whitney test between the collections from 2009 to 2011 in the two different neighborhoods is that T. melanocephalum was found in the peridomiciliar area in Itaquera and Vila Mariana equally. Peridomiciliar in these neighborhoods was different, with more gardens and backyards in Vila Mariana. But T. melanocephalum occurrence outdoors was lower than indoors, in both neighborhoods, probably due to the competition with other ant species and to abiotic factors such as temperature and moisture. In a survey conducted in 2009 by Wetterer [10], he reports that the ghost ant is restricted to indoors once the species can live wherever man is. He also emphasizes that it is found in tropical and subtropical zones in latitudes higher than $30^{\circ}$. MacGown and Hill [28] confirm this statement and comment that, besides, it is found in the United States and in some states in Canada; the occurrences are in greenhouses and other warm places, strengthening that temperature influences its distribution, but it can be solved when occupies human dwellings with controlled temperature. In our work, T. melanocephalum was found mainly in the indoors even though there were differences among houses and human habits in both neighborhoods. Menke et al. [26] also highlight the role of cities as a refuge for generalist species that show more tolerance to dryer and hotter environments.

Differences in the environment outdoors are not significant for $T$. melanocephalum once this is not the most favorable environment for its establishment.

Itaquera has a recent urbanization process; new households, streets, and avenues have been continually built as other landscape transformation caused by such processes, what may favor opportunistic ant species with flexible adjustments to such disturbances, like T. melanocephalum. 
Many authors discuss this fact like Tschinkel [16] who suggested that $S$. invicta whose native environment is seasonally flooded and is a species that easily adapts to highly disturbed environments, even in different continents. When native ant populations were compared with invasive/exotic ant species in recent and ancient urban areas, the exotic species succeed in establishing in recent urbanized areas [29], while the native species remained in the ancient urban areas. Native and exotic species distribution in a city is still a not very well-explained question although the preference from exotic species for disturbed environments is known. Studies suggest that there is a series of relationships between biotic and abiotic factors that makes this question so complex $[18,19]$.

This explains the species richness found in Itaquera compared to Vila Mariana and the high dominance by T. melanocephalum in the former neighborhood, a still unknown ant species but intimately linked to the São Paulo citizens.

Yet, the number of houses with several ant species in Itaquera is related to the green area that surrounds the neighborhood and many species that are not common to urban areas like Acromyrmex sp., C. crassus, C. rufipes, Cyphomyrmex sp., Linepithema spp., Octostruma sp., and 9 Pheidole species. The bad conservation of houses in Itaquera also may contribute to the establishment of ants inside and in the peridomiciliar areas of the houses.

\section{Acknowledgment}

The authors thank those residents who permitted the ant collections in their homes. This paper was presented at the 7th International Conference on Urban Pests, in Ouro Preto, August, 2011.

\section{References}

[1] D. A. Holway, L. Lach, A. V. Suarez, N. D. Tsutsui, and T. J. Case, "The causes and consequences of ant invasions," Annual Review of Ecology and Systematics, vol. 33, pp. 181-233, 2002.

[2] J. H. Delabie, I. C. Nascimento, P. Pacheco, and A. B. Casimiro, "Community structure of house-infesting ants (Hymenoptera: Formicidae) in southern Bahia, Brazil," Florida Entomologist, vol. 78, no. 2, pp. 264-270, 1995.

[3] A. Piva and A. E. C. Campos-Farinha, "Estrutura de comunidade das formigas urbanas do bairro da Vila Mariana na cidade de São Paulo," Naturalia, vol. 24, pp. 115-117, 1999.

[4] N. S. Soares, L. D. O. Almeida, C. A. Gonçalves, M. T. Marcolino, and E. A. M. Bonetti, "Survey of ants (Hymenoptera: Formicidae) in the urban area of Uberlândia, MG, Brazil," Neotropical Entomology, vol. 35, no. 3, pp. 324-328, 2006.

[5] R. Pacheco and H. L. Vasconcelos, "Invertebrate conservation in urban areas: Ants in the Brazilian Cerrado," Landscape and Urban Planning, vol. 81, no. 3, pp. 193-199, 2007.

[6] W. M. Wheeler, "The ants of Porto Rico and the Virgin Islands," Bulletin of the American Museum of Natural History, vol. 24, pp. 117-158, 1908.

[7] J. K. Wetterer and B. C. O'Hara, "Ants (Hymenoptera: Formicidae) of the dry tortugas, the outermost Florida Keys," Florida Entomologist, vol. 85, no. 2, pp. 303-307, 2003.
[8] C. Vanderwoude, L. A. Lobry De Bruyn, and A. P. N. House, "Response of an open-forest ant community to invasion by the introduced ant, Pheidole megacephala," Austral Ecology, vol. 25, no. 3, pp. 253-259, 2000.

[9] B. D. Hoffmann and C. L. Parr, "An invasion revisited: the African big-headed ant (Pheidole megacephala) in northern Australia," Biological Invasions, vol. 10, pp. 1171-1181, 2008.

[10] J. K. Wetterer, "Worldwide spread of the ghost ant, Tapinoma melanocephalum (hymenoptera: For-micidae)," Myrmecological News, vol. 12, pp. 23-33, 2009.

[11] M. F. M. Zarzuela, M. C. C. Ribeiro, and A. E. C. CamposFarinha, "Distribuição de formigas em um hospital da região sudeste do Brasil," Arquivos do Instituto Biológico, vol. 69, no. 1, pp. 85-87, 2002.

[12] C. M. Kamura, M. S. C. Morini, C. J. Figueiredo, O. C. Bueno, and A. E. C. Campos-Farinha, "Ant communities (Hymenoptera: Formicidae) in an urban ecosystem near the Atlantic Rainforest," Brazilian Journal of Biology, vol. 67, no. 4, pp. 635641, 2007.

[13] A. E. C. Campos-Farinha, J. J. Justi, E. C. Bergmann, F. J. Zorzenon, and S. M. R. Netto, "Formigas Urbanas," Bol. Técn. Inst. Biol., no. 8, pp. 5-20, 1997.

[14] J. H. Klotz, J. R. Mangold, K. M. Vail, L. R. Davis Jr., and R. S. Patterson, "A survey of the urban pest ants (Hymenoptera: Formicidae) of Peninsular Florida," Florida Entomologist, vol. 78, no. 1, pp. 109-118, 1995.

[15] S. Cremer, L. V. Ugelvig, F. P. Drijfhout et al., "The evolution of invasiveness in garden ants," PLoS One, vol. 3, no. 12, Article ID e3838, 2008.

[16] W. R. Tschinkel, "Distribution of the fire ants Solenopsis invicta and S. geminata (Hymenoptera: Formicidae) in northern Florida in relation to habitat and disturbance," Annals of the Entomological Society of America, vol. 81, no. 1, pp. 76-81, 1988.

[17] K. M. Clarke, B. L. Fisher, and G. LeBuhn, "The influence of urban park characteristics on ant (Hymenoptera, Formicidae) communities," Urban Ecosystems, vol. 11, no. 3, pp. 317-334, 2008.

[18] E. A. Forys and C. R. Allen, "The impacts of sprawl on biodiversity: the ant fauna of the lower Florida Keys," Ecology and Society, vol. 10, no. 1, article no. 25, 2005.

[19] M. Pećarević, J. Danoff-Burg, and R. R. Dunn, "Biodiversity on broadway-enigmatic diversity of the societies of ants (formicidae) on the streets of New York City," PLoS One, vol. 5, no. 10, Article ID e13222, 2010.

[20] J. P. Lessard and C. M. Buddle, "The effects of urbanization on ant assemblages (Hymenoptera: Formicidae) associated with the Molson Nature Reserve, Quebec," Canadian Entomologist, vol. 137, no. 2, pp. 215-225, 2005.

[21] S. Siegel and N. J. Castellan Jr., Estatística Não-Paramétrica para Ciências do Comportamento, Artmed, Porto Alegre, Brazil, 2006.

[22] SAS Institute Inc, The SAS System for Windows (Statistical Analysis System), version 8.02., Cary, NC, USA, 1999-2001.

[23] G. C. Thomas, "Biodap - Ecological, Diversity and its measurement," 2010, http://nhsbig.inhs.uiuc.edu/populations/ bio-dap.zip.

[24] P. Chacón de Ulloa, "Urban ants," in Introduction to the Ants in the Neotropics, F. Fernández, Ed., pp. 351-359, Research Institute of Biological Resources Alexander von Humboldt, Bogotá, Colombia, 2003. 
[25] H. G. Fowler, M. N. Schlindwein, and M. A. Medeiros, "Exotic ants and community simplification in Brazil: a review of the Impact of exotic ants on native ant assemblages," in Exotic Ants: Biology, Impact and Control of Introduced Species, D. F. Williams, Ed., pp. 151-162, Westview Press, Boulder, Colo, USA, 1994.

[26] S. B. Menke, B. Guénard, J. O. Sexton, M. D. Weiser, R. R. Dunn, and J. Silverman, "Urban areas may serve as habitat and corridors for dry-adapted, heat tolerant species: an example from ants," Urban Ecosystems, vol. 14, pp. 135-163, 2011.

[27] O. C. Bueno and A. E. C. Campos-Farinha, "As formigas domésticas," in Insetos e Outros Invasores de Residências, F. A. M. Mariconi, Ed., pp. 135-180, FEALQ, Piracicaba, Brazil, 1999.

[28] J. MacGown and J. V. G. Hill, "Tapinoma melanocephalum (Hymenoptera: Formicidae), a new exotic ant," Journal of the Mississipi Academy of Sciences, vol. 54, pp. 172-174, 2009.

[29] R. M. Plowes, J. G. Dunn, and L. E. Gilbert, "The urban fire ant paradox: native fire ants persist in an urban refuge while invasive fire ants dominate natural habitats," Biological Invasions, vol. 9, no. 7, pp. 825-836, 2007. 

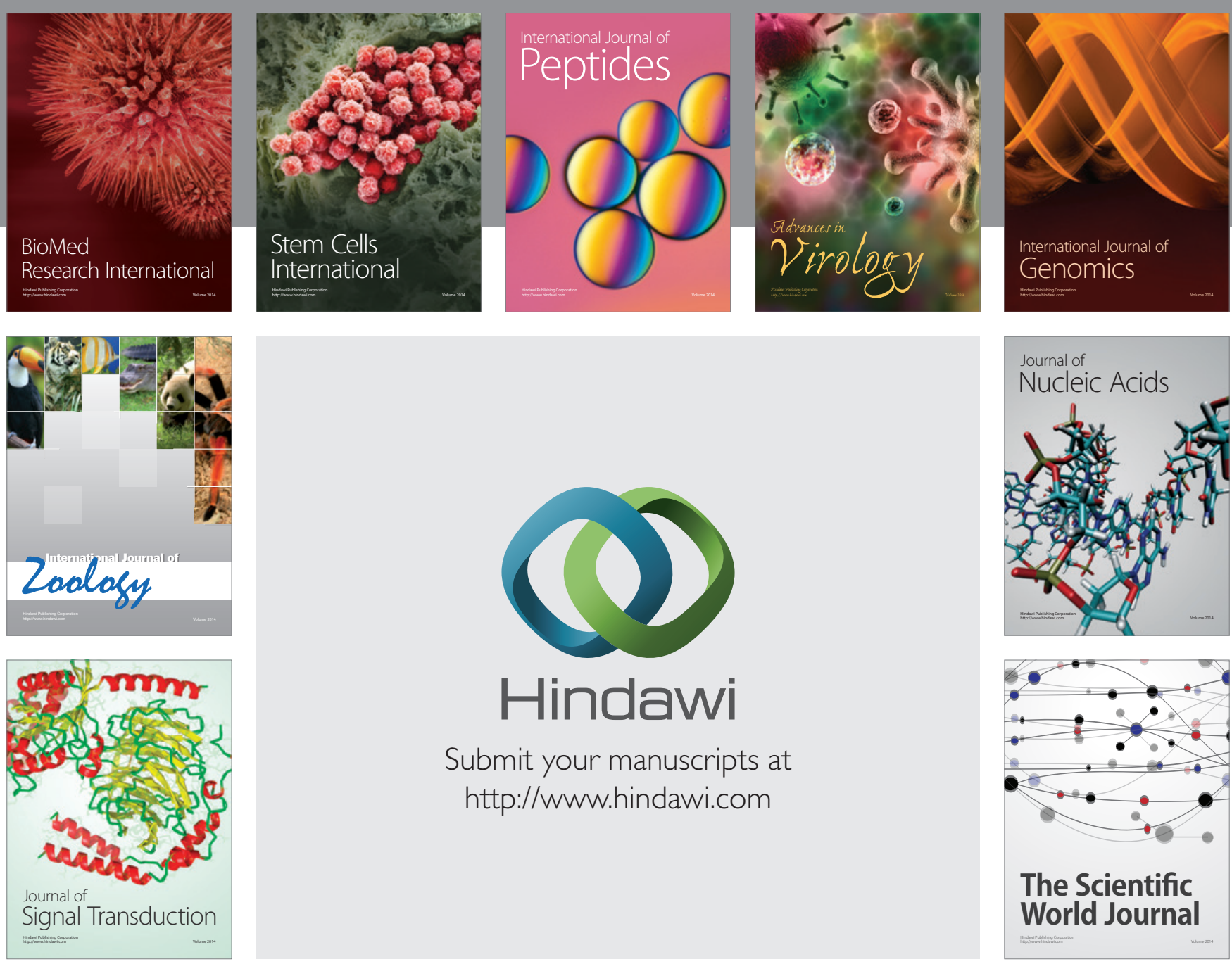

Submit your manuscripts at

http://www.hindawi.com
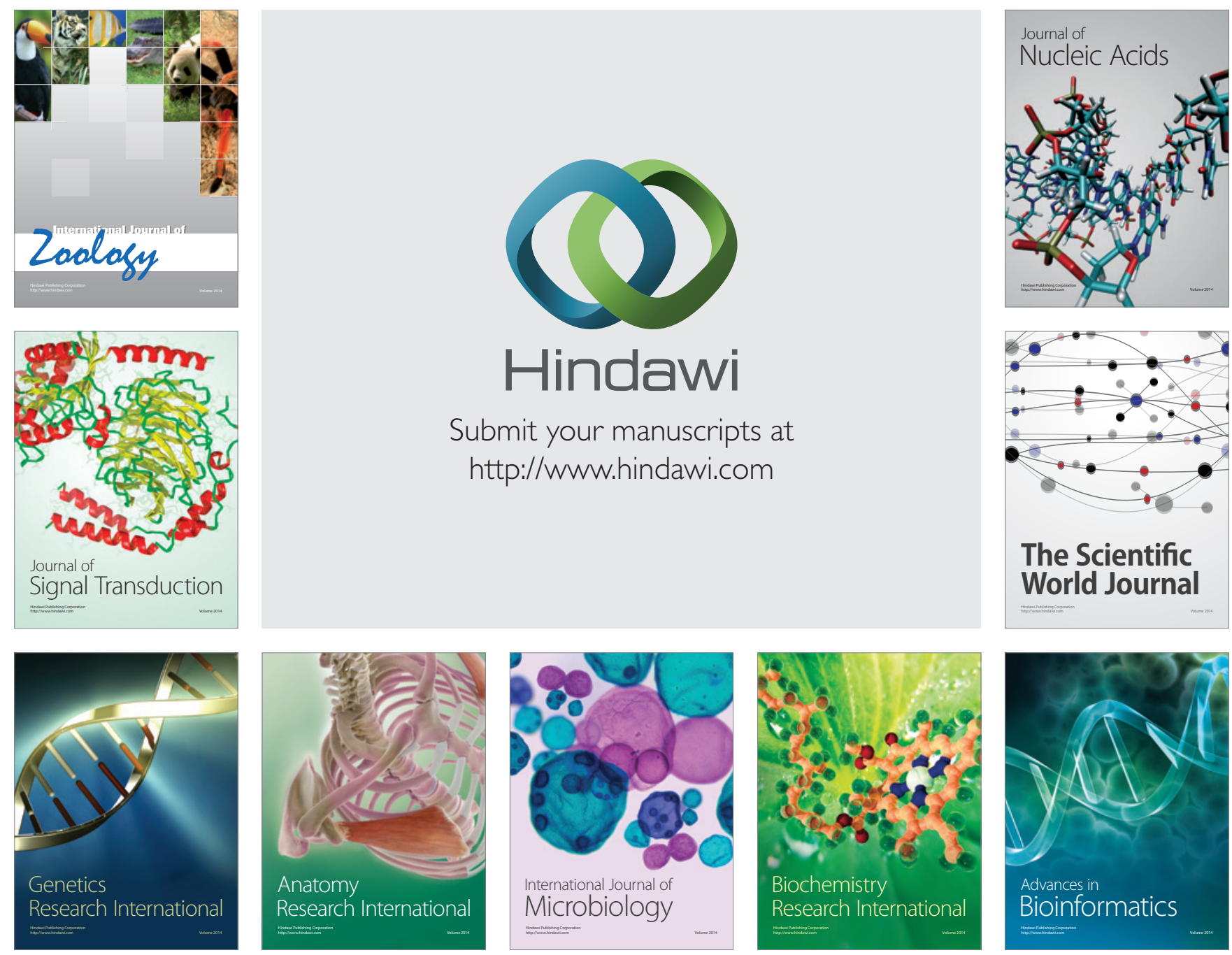

The Scientific World Journal
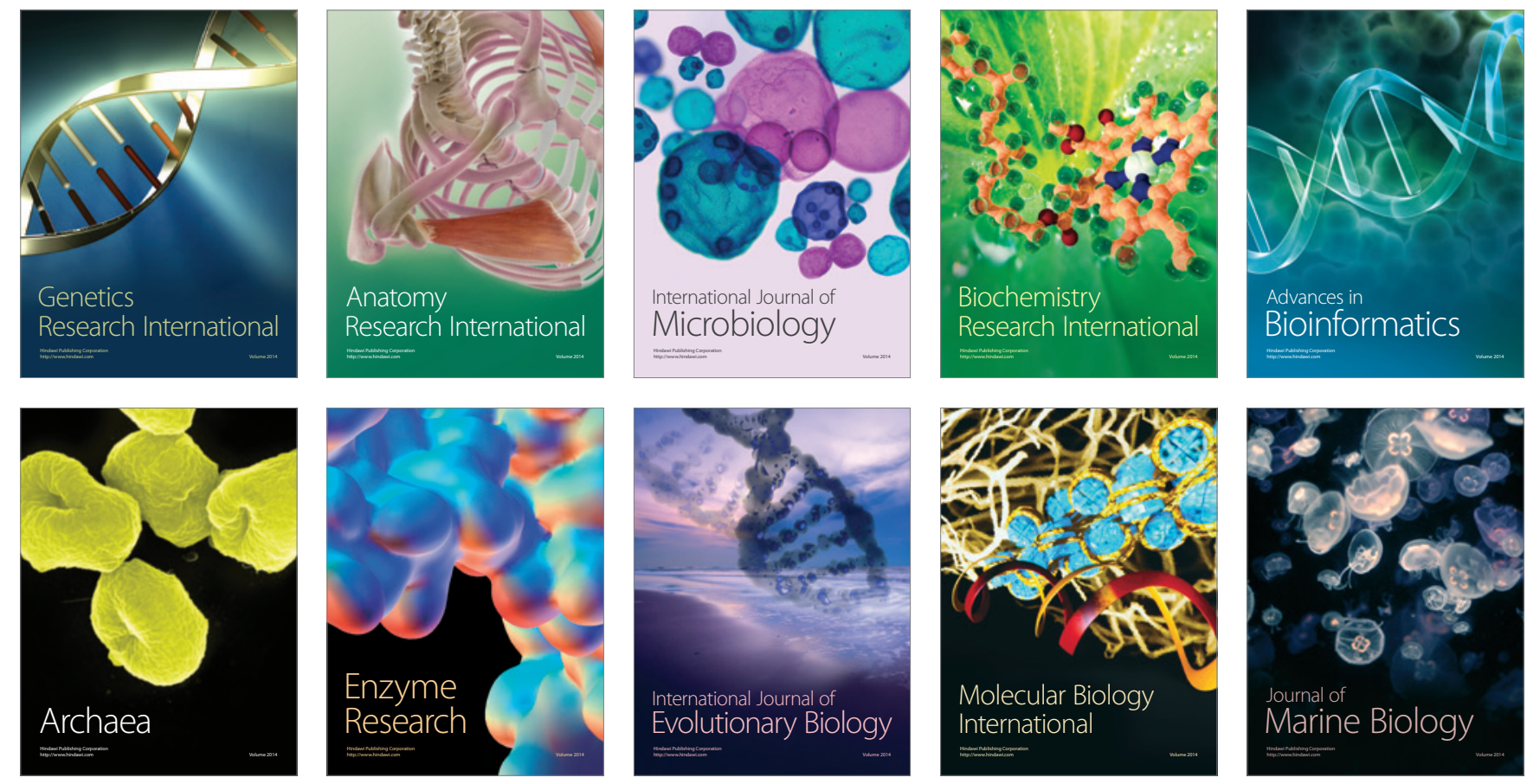